\title{
IMPLEMENTASI ALGORITMA RIJNDAEL DALAM ENKRIPSI DAN DEKRIPSI GAMBAR DIGITAL BERBASIS WEB
}

\author{
Ade Chandra Saputra ${ }^{\text {a }}$, Agus Sehatman Saragih ${ }^{b}$ \\ ${ }^{a}$ Universitas Palangka Raya, J1.H.Timang Palangka Raya \\ ${ }^{\mathrm{b}}$ Universitas Palangka Raya, Jl.H.Timang Palangka Raya \\ ${ }^{1}$ adechandra@it.upr.ac.id; ${ }^{2}$ asaragih @ gmail.com \\ * corresponding author
}

\section{ARTICLE INFO}

Keywords

Rijndael algorithm

Image Security System.

\author{
ABSTRACT (10PT)
}

More and more abuse of digital images, data or information that is personal in nature can be easily known by others who are not entitled through digital images. This can cause material and immaterial losses to people whose personal information is misused by others. Then the application applies the Rijndael algorithm to secure digital image images which contain information or data that is personal in nature. In securing digital images, the Rijndael algorithm is used to protect the information contained in these images, this algorithm runs with processes such as SubBytes, ShiftRows, MixColumns, and AddRoundKey. The methodology applied is data collection methods such as field studies and literature studies, then methods of developing Waterfall software (Communication, Planning, Modeling, Construction, and Deployment) for system design. The results of the test analysis get an accuracy value of $100 \%$ from the 14 image files tested, all of them were successfully encrypted and decrypted so that it returned to the original form of the original image. For further development, this application can input the data files of other documents and increase the key length to 196 bits and 256 bits.

\section{Pendahuluan}

Keamanan adalah keadaan bebas dari bahaya. Keamanan dapat diimplementasikan kedalam berbagai hal, termasuk data dan informasi. Data merupakan salah satu aset penting dalam kelangsungan hidup perusahaan, instansi - instansi pemerintahan, institusi - institusi pendidikan bahkan untuk pribadi. Semua orang memiliki sesuatu yang ingin keamanannya terjaga dan tidak terpublikasi dengan mudah, seperti uang, surat-surat berharga, barang-barang berharga dan lain-lain. Tidak hanya berhenti di situ saja yang membutuhkan keamanan, namun data atau informasi yang dimiliki, membutuhkan keamanan yang memadai, karena data atau informasi merupakan salah satu aset yang penting, yang jika tidak dijaga dengan baik dapat menimbulkan kerugian materil atau immateril. Data atau informasi tersebut dapat berupa teks, citra/gambar, audio, dan video. Dengan adanya kemajuan teknologi, data atau informasi dapat disajikan dalam bentuk digital. Akan tetapi, bentuk penyimpanan seperti ini sangat rentan aspek keamanannya. Data dapat dengan mudah diganti, dimanipulasi, dihilangkan, atau bahkan disalahgunakan. Salah satu data yang sering dimanipulasi dan disalahgunakan adalah gambar digital. Gambar yang dimanipulasi dapat merusak nama baik seseorang. Hal ini tentu saja melanggar hak privasi setiap orang. Dengan demikian usaha dalam mengamankan data digital menjadi hal yang sangat penting dan sangat mendesak. Adapun masalah keamanan dalam suatu data atau informasi dapat diatasi salah satunya dengan menerapkan kriptografi, yaitu ilmu atau seni yang menggunakan matematika untuk mengamankan suatu informasi. Pengamanan ini dilakukan dengan menjalankan algoritma enkripsi (mengubah informasi awal menjadi informasi baru yang disamarkan dengan menggunakan suatu kunci) dan dekripsi (mengubah kembali menjadi informasi awal). 
Hampir setiap orang menjadikan gambar digital sebagai sarana untuk menyimpan informasi penting, misalnya bukti-bukti transaksi, surat-surat berharga, foto-foto yang berisikan informasi pribadi yang tidak ingin dipublikasikan dan lain-lain. Hal inilah yang menyebabkan perlindungan gambar digital menjadi sangat penting.

Permasalahan yang akan dibahas pada jurnal ini adalah sebagai berikut :

1. Bagaimana implementasi algoritma Rijndael dalam enkripsi gambar digital sehingga gambar digital tidak dapat dibaca atau dimengerti oleh pihak lain yang tidak berhak ?

2. Bagaimana hasil dekripsi dapat mengembalikan file hasil enkripsi ke bentuk awal ?

Berdasarkan rumusan masalah di atas, maka tujuannya adalah untuk mengimplementasikan Algoritma Rijndael yang dapat digunakan untuk mengenkripsi dan dekripsi gambar digital. Sehingga gambar digital tidak dapat dilihat dan dibaca oleh orang yang tidak berhak atau tidak memiliki kata kunci untuk dekripsi. Hal ini guna mengamankan hak-hak dan privasi pribadi terhadap informasi yang terkandung didalamnya.

\section{Metodologi Penelitian}

Jelaskan metode preparasi dan teknik karakterisasi yang digunakan. Jelaskan dengan ringkas, tetapi tetap akurat seperti ukuran, volume, replikasi dan teknik pengerjaan. Untuk metode baru harus dijelaskan secara rinci agar peneliti lain dapat mereproduksi percobaan. Sedangkan metode yang sudah mapan bisa dijelaskan dengan memetik rujukan.

\subsection{Metode Pengembangan Sistem}

Dalam tahap perancangan sistem ini menggunakan metode Waterfall (Roger S. Pressman, 2010) dengan tahap-tahap sebagai berikut :

\section{Communication (Komunikasi)}

Pada tahap ini merupakan tahap analisis terhadap kebutuhan software, dan tahap untuk mengadakan pengumpulan data yang diperlukan. Hasil pada tahap komunikasi yaitu data-data yang dibutuhkan dalam pembuatan sistem.

2. Planning (Perencanaan)

Proses perencanaan merupakan lanjutan dari proses communication (komunikasi). Tahapan ini akan menghasilkan dokumen user requirement atau bisa dikatakan sebagai data yang berhubungan dengan keinginan user dalam pembuatan software, termasuk rencana yang akan dilakukan.

3. Modeling (Pemodelan)

Proses modeling ini akan menerjemahkan syarat kebutuhan ke sebuah perancangan software yang dapat diperkirakan sebelum dibuat coding. Proses ini terbagi menjadi 2, yaitu analisis dan desain. Pada analisis menggunakan Data Flow Diagram (DFD) yang akan menghasillkan context diagram.. Pada desain akan mendesain tabel, desain navigasi menggunakan Sitemap dan desain antarmuka/representasi interface.

4. Construction (Konstruksi)

Construction merupakan proses membuat kode (coding). Coding atau pengkodean merupakan penerjemahan desain dalam bahasa yang bisa dikenali oleh komputer. Programmer akan menerjemahkan transaksi yang diminta oleh user. Tahapan inilah yang merupakan tahapan secara nyata dalam mengerjakan suatu software, artinya penggunaan komputer akan dimaksimalkan dalam tahapan ini. Setelah pengkodean selesai maka akan dilakukan testing terhadap sistem yang telah dibuat tadi. Tujuan testing adalah menemukan kesalahan-kesalahan terhadap sistem tersebut untuk kemudian bisa diperbaiki. Untuk menerjemahkan kode-kode program dengan menggunakan bahasa pemrograman PHP dan pengujian dilakukan menggunakan Blackbox Testing.

5. Deployment (Penyerahan)

Tahapan ini merupakan tahap akhir dalam pembuatan sebuah software atau sistem. Setelah melakukan analisis, desain dan pengkodean maka sistem yang sudah jadi akan digunakan oleh user. Kemudian software yang telah dibuat harus evaluasi jika ada kekurangan dan dilakukan pemeliharaan secara berkala. 


\subsection{Arsitektur Sistem}

Arsitektur Sistem Adapun tahapan dalam enkripsi dan dekripsi gambar digital adalah sebagai berikut :

a. Langkah pertama yang dilakukan adalah program akan menampilkan halaman utama sebagai menu yang memberikan pilihan kepada pengguna untuk memilih enkripsi atau dekripsi.

b. Langkah kedua adalah memilih fitur yang ingin dijalankan baik itu enkripsi maupun dekripsi.

c. Langkah ketiga, pengguna akan diminta memasukan file citra gambar untuk enkripsi atau file citra terenkripsi untuk dekripsi.

d. Langkah keempat, pengguna diminta memasukan kunci dengan Panjang maksimal 16 karakter.

e. Langkah kelima, pengguna melakukan proses enkripsi dan dekripsi sebagaimana fitur yang dipilih.

f. Program menampilkan rincian dan mengeluarkan output file-file yang telah diolah berdasarkan fitur.

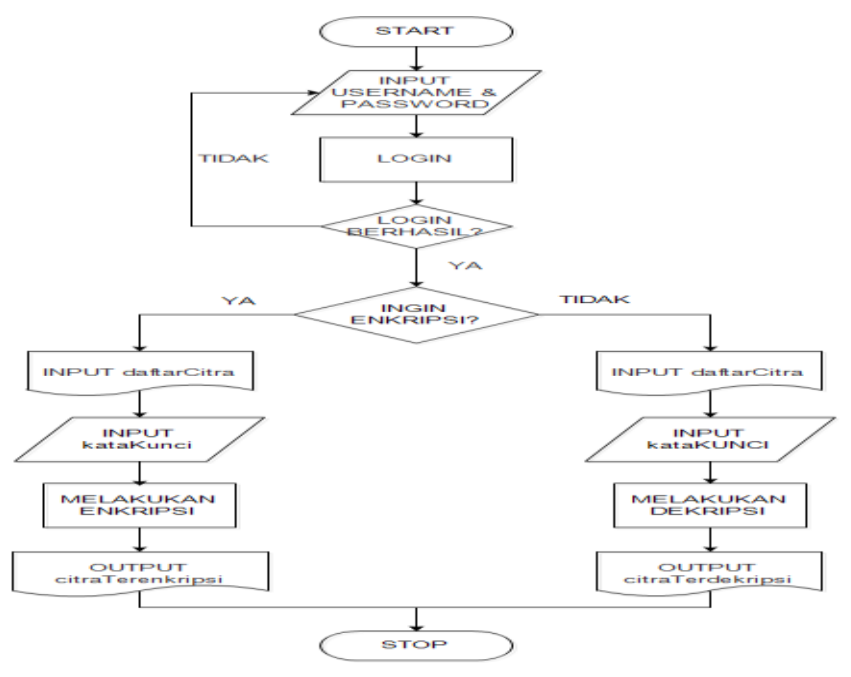

Gambar 1 Arsitektur Sistem

Gambar 1 menjelaskan cara kerja aplikasi dari awal sampai berakhir, dimulai dari kegiatan login, input file gambar dan kunci, kemudian memilih fitur enkripsi atau dekripsi yang akan dilakukan kemudian aplikasi akan mengeluarkan output berupa file gambar digital.

Gambar 2 menjelaskan cara kerja algoritma rijndael dalam mengenkripsi file gambar digital. AddRoundKey pada dasarnya adalah mengkombinasikan chiper teks yang sudah ada dengan roundkey dengan hubungan XOR. Kemudian untuk enkripsi 128 bit memerlukan iterasi sebanyak 10 kali, iterasi ini berisi proses subbytes yaitu menukar ini matriks dengan tabel pada rijndael S-Box, shiftrows yaitu sebuah proses dengan melakukan pergeseran pada tiap baris, mixcolumns yaitu mengalikan tiap elemen dari blok chiper dengan matriks, AddRoundKey. 


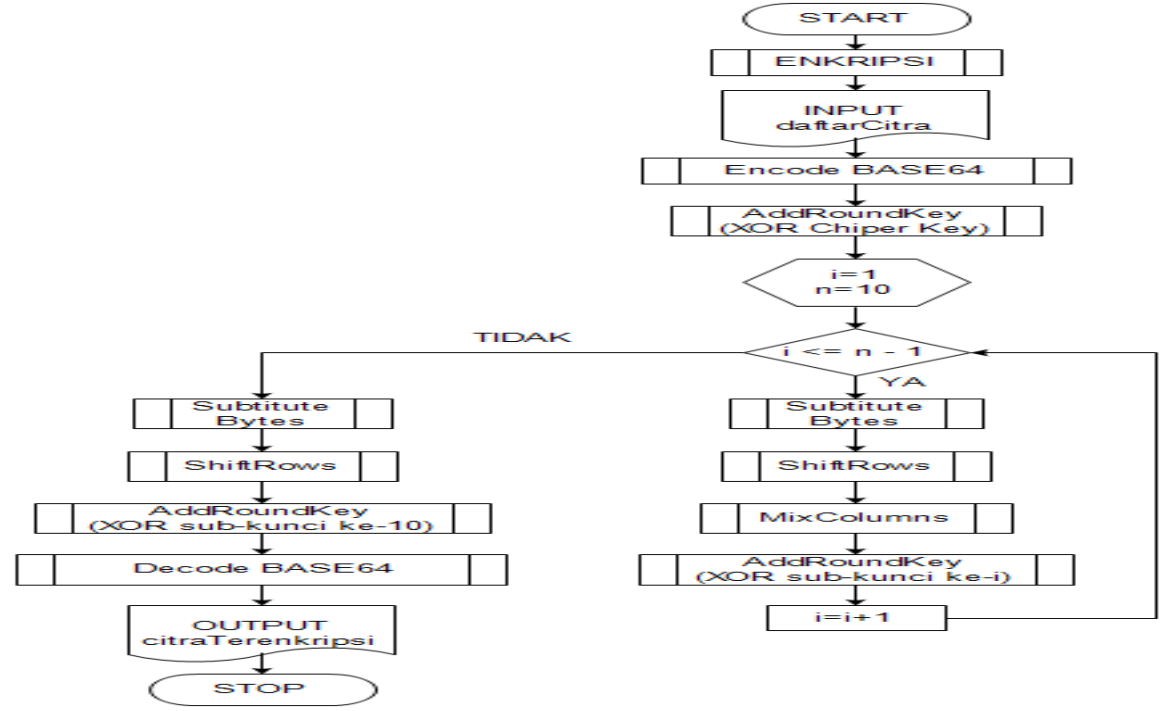

Gambar 2 Arsitektur Enkripsi Rijndael

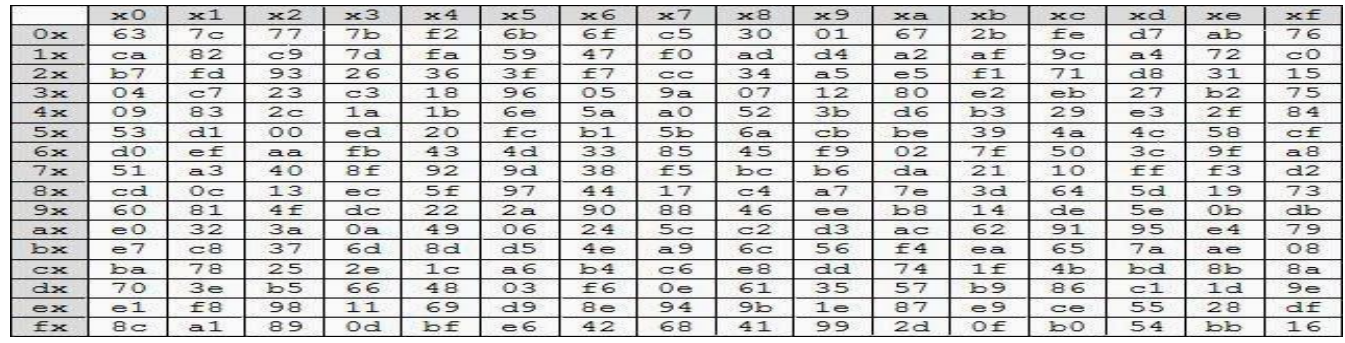

Gambar 3 Tabel S-Box

Gambar 3 merupakan tabel S-Box yang digunakan saat melakukan subBytes. Elemen dari matriks awal akan berubah nilainya karena dikombinasikan atau dicocokan nilainya dengan nilai baru yang ada pada tabel S-box.

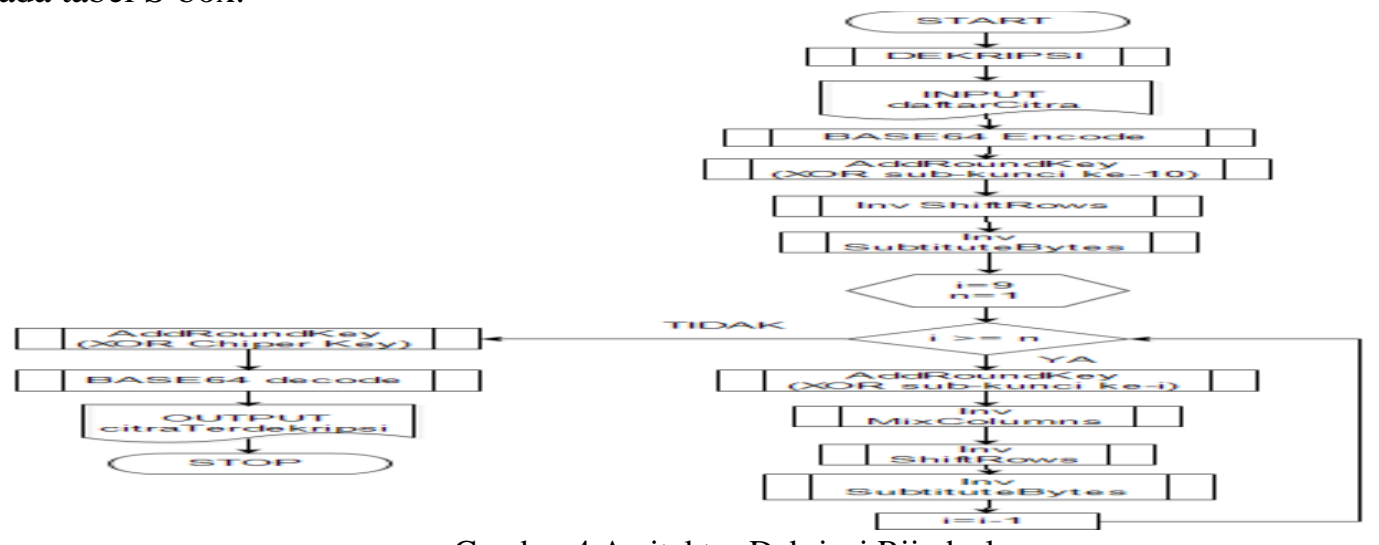

Gambar 4 Arsitektur Dekripsi Rijndael

Gambar di 4 adalah alur kerja dekripsi, proses yang dilakukan pada dekripsi merupakan kebalikan dari proses enkripsi. XOR dengan subkunci ke 10 merupakan hal pertama kali yang dilakukan kemudian melakukan pergeseran baris secara terbalik dan menukar isi matriks dengan S-Box (gambar 4). kemudian melakukan iterasi sebanyak 10 kali dengan addRoundKey, MixColumns, ShiftRows, 
dan SubBytes secara terbalik. Dan yang terakhir melakukan XOR pada chiperkey sehingga sistem menghasilkan output berupa gambar digital seperti aslinya.

\section{Hasil dan Pembahasan}

Pembahasan terhadap hasil implemantasi yang dirancang terdapat dua jenis pengujian yang dilakukan adalah :

1. Pengujian hasil dekripsi apakah sama dengan file awal yang di-input.

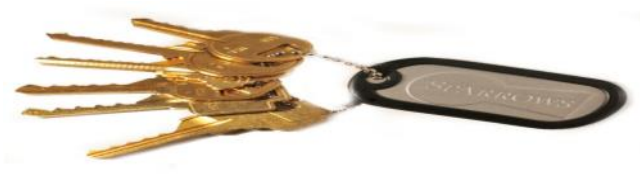

Gambar 1 File Input citra RGB dengan format JPG

Program diberikan inputan berupa file citra berwarna dengan format JPG dan dengan menggunakan kunci "teskunci" sehingga menghasilkan file terenkripsi seperti gambar 5, dimana ukuran citra gambar sebelum dienkripsi adalah $43,4 \mathrm{~Kb}$ dan setelah dienkripsi menjadi $57,9 \mathrm{~Kb}$, serta durasi proses enkripsi adalah 0,004 detik.

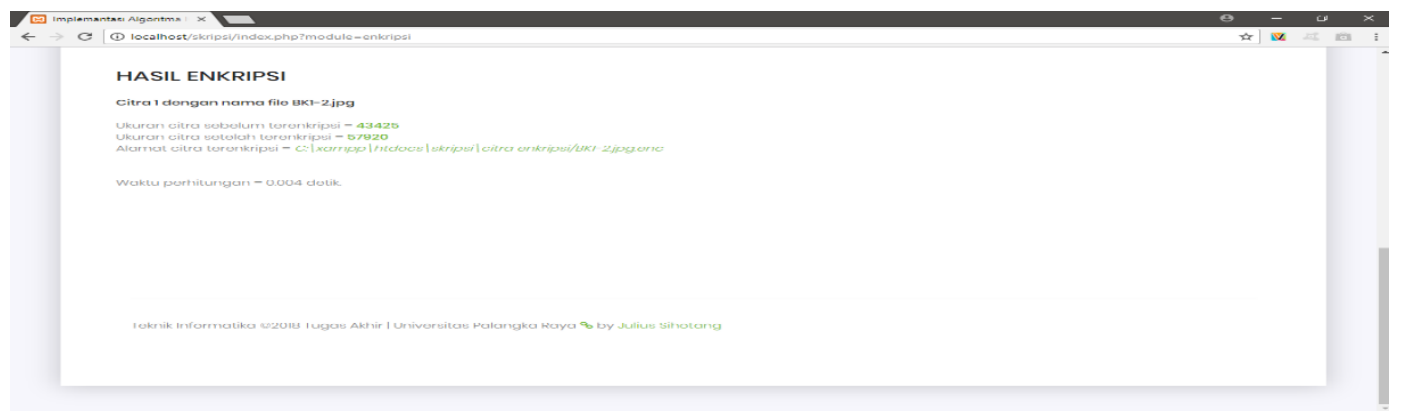

Gambar 2 Hasil Enkripsi File Input Citra RGB dengan format JPG

Program kemudian diberikan input-an berupa file yang telah dienkripsi sehingga menghasilkan seperti gambar 6. Program menampilkan ukuran file terenkripsi sebesar 57,9 $\mathrm{Kb}$, ukuran file setelah didekripsi sebesar 43,4 Kb, dan durasi proses dekripsi adalah 0,004 detik.

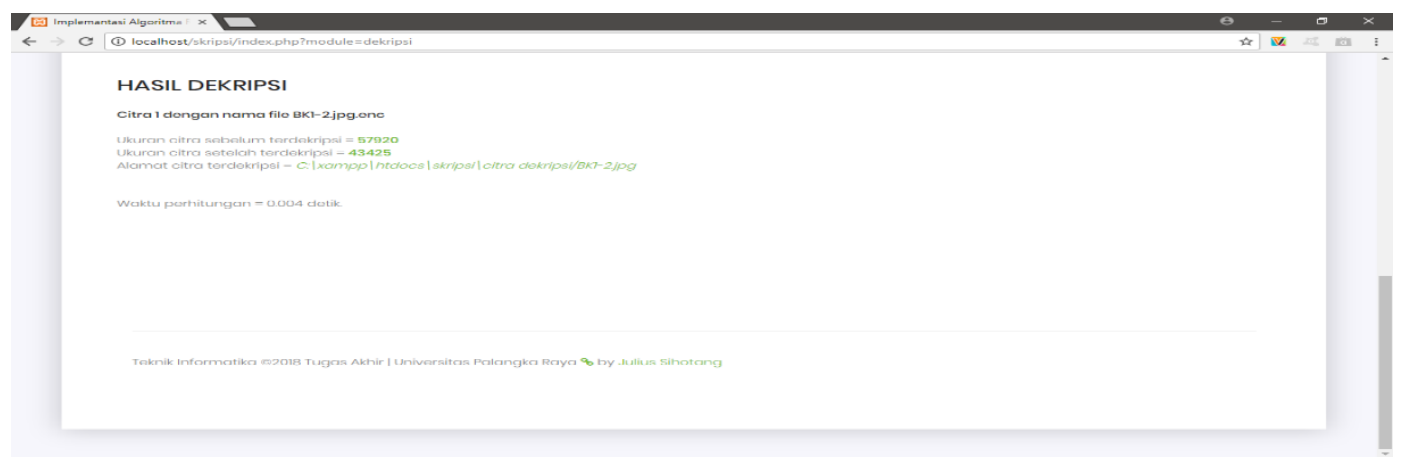

Gambar 3 Program Melakukan Dekripsi File Input Citra Terenkripsi

Gambar 7 menampilkan citra yang telah didekripsi memiliki kesamaan seperti citra sebelum dienkripsi, sehingga dapat dipastikan program berjalan dengan baik pada citra RGB berformat JPG. 


\section{JURNAL TEKNOLOGI INFORMASI}

Jurnal Keilmutan dan Aplikasi Bitang Teknik Informatika
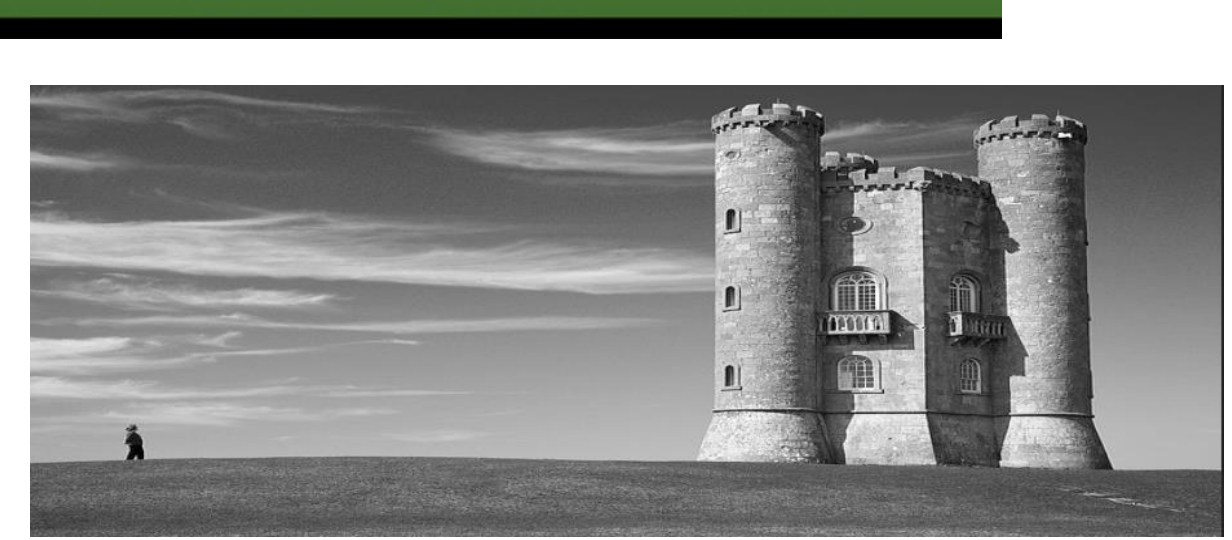

Gambar 4 File Input citra Grayscale dengan format JPG

Gambar 8 menampilkan file citra grayscale yang akan dienkripsi menggunakan program dengan kunci "teskunci". Program melakukan eksekusi fungsi enkripsi pada file citra grayscale, program menampilkan hasil seperti gambar 8, dimana ukuran citra gambar sebelum dienkripsi adalah $88,3 \mathrm{~Kb}$ dan setelah dienkripsi menjadi $117,8 \mathrm{~Kb}$, serta durasi proses enkripsi adalah 0,006 detik.

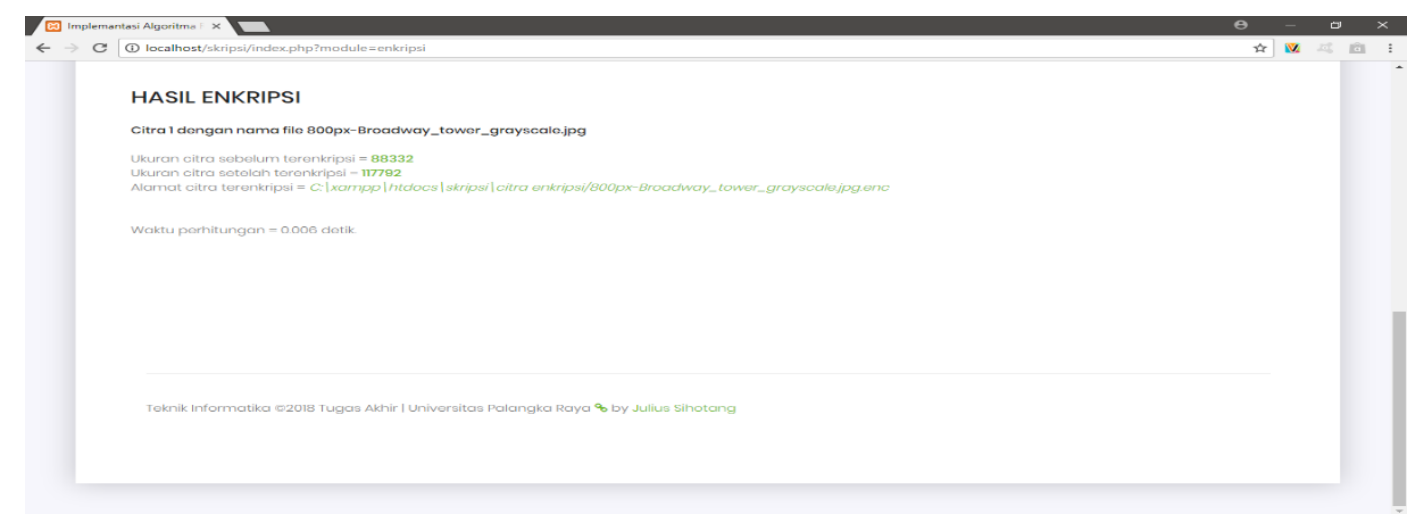

Gambar 5 Program Melakukan Enkripsi Pada Citra Grayscale

Program kemudian diminta untuk melakukan dekripsi pada file citra terenkripsi sebelumnya. Program menampilkan hasil proses dekripsi yang berisi informasi seperti gambar 4.14 yaitu ukuran citra sebelum terdekripsi sebesar $117,8 \mathrm{~Kb}$, ukuran setelah terdekripsi sebesar $88,3 \mathrm{~Kb}$, dan mengalami proses selama 0,07 detik.

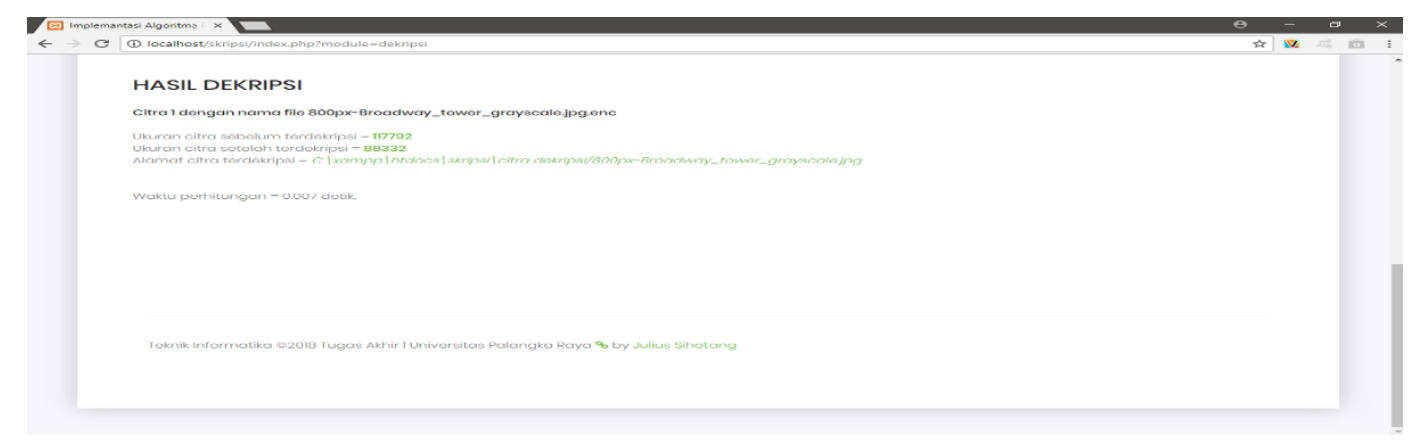

Gambar 6 Program Melakukan Dekripsi Pada Citra Grayscale

Hasil dari dekripsi file citra terenkripsi kemudian dibuka menggunakan aplikasi penampil gambar dan menampilkan gambar sesuai dengan gambar sebelum dienkripsi. 


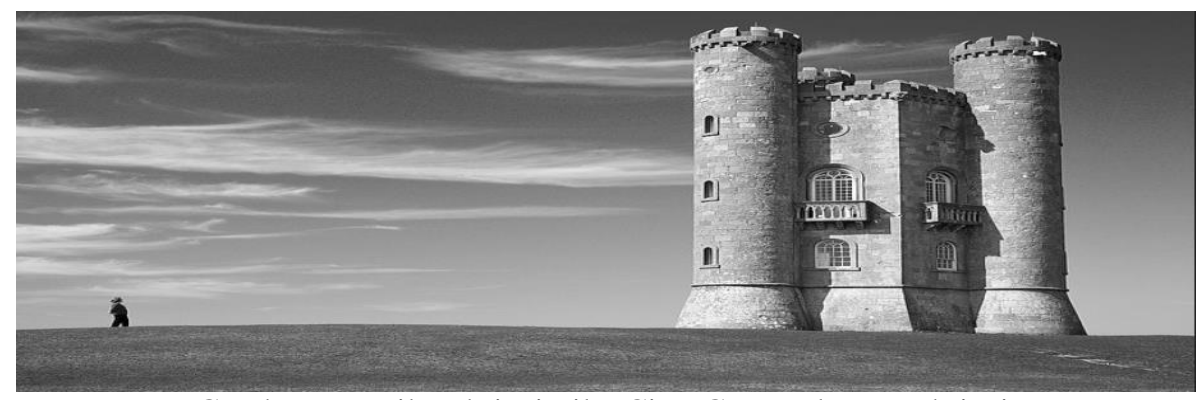

Gambar 7 Hasil Dekripsi File Citra Grayscale Terenkripsi

2. Durasi enkripsi dan dekripsi jenis file citra (RGB atau Grayscale) dengan ukuran dan kunci yang sama. Kedua gambar sebelumnya dilakukan resize menjadi 500 x 500 pixel dengan aspek rasio 1:1 sehingga mendapatkan ukuran lebar dan tinggi yang sama untuk menghasilkan pengukuran waktu proses yang lebih efektif.

Tabel 1 Pengujian Durasi Enkripsi Terhadap Jenis Citra

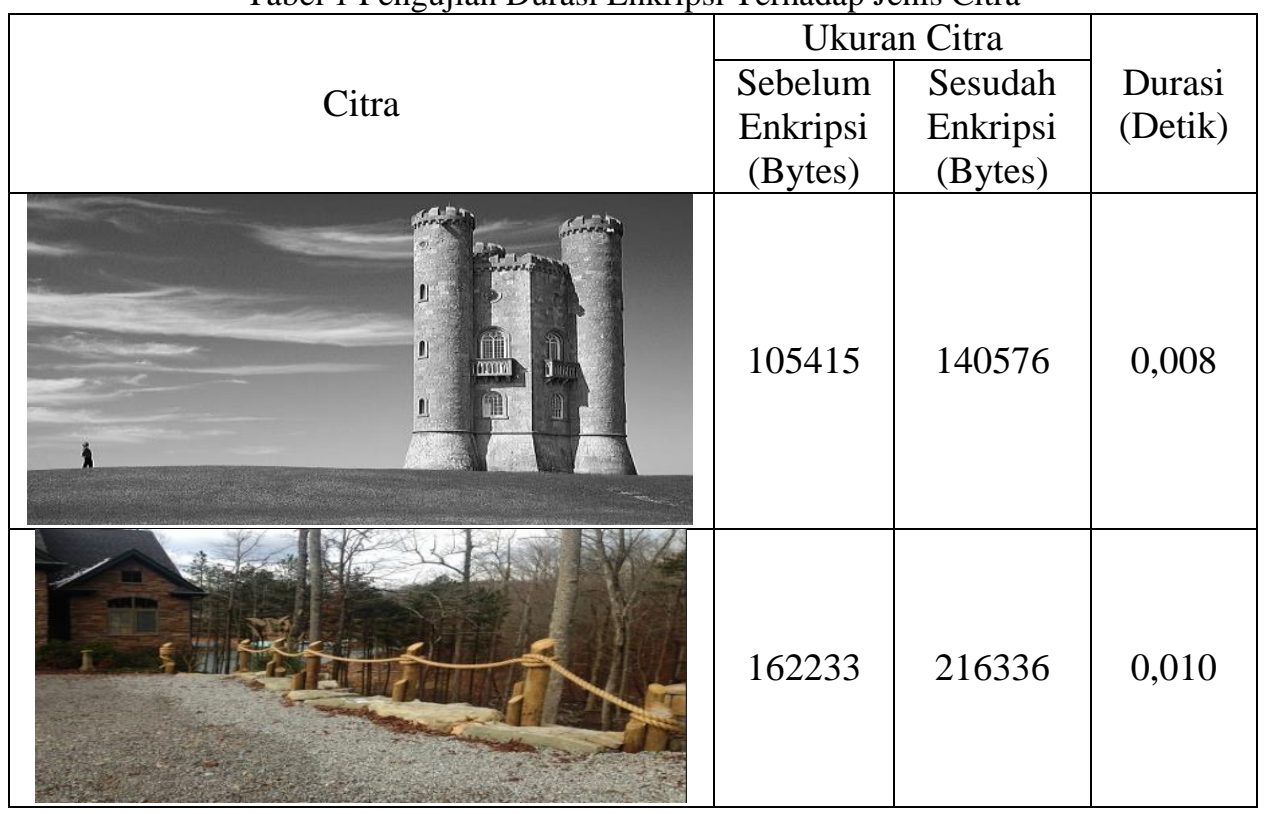

Tabel 2 Pengujian Durasi Dekripsi Terhadap Jenis Citra

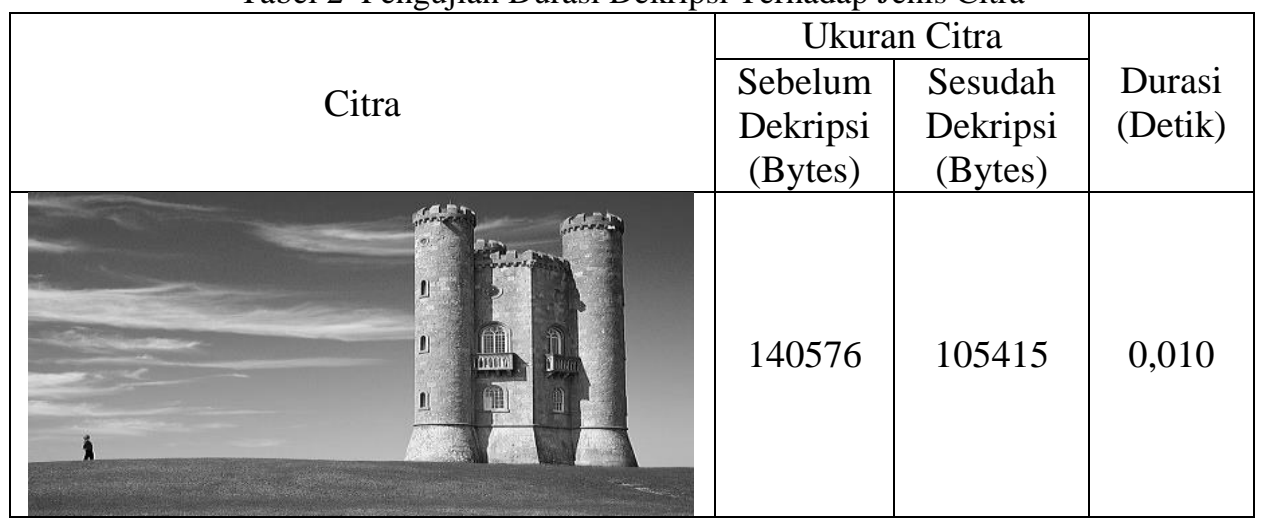




\section{(1)}

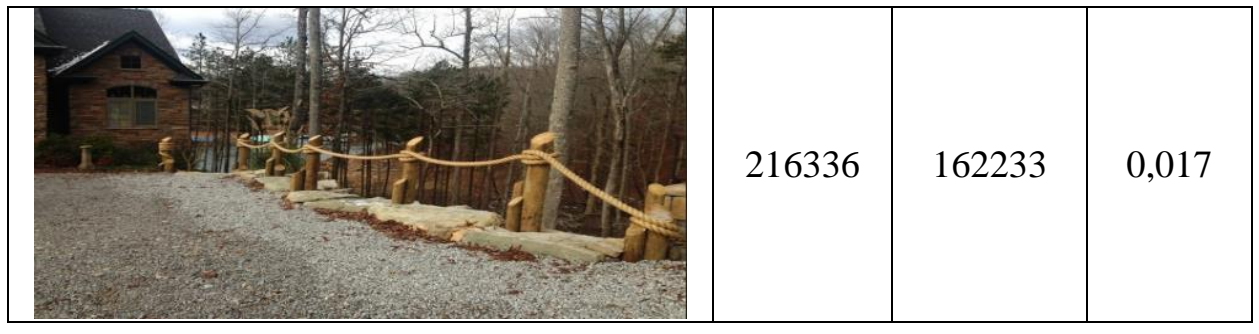

Dari hasil pengujian diatas didapatkan hasil bahwa citra grayscale dan RGB dengan resolusi yang sama yaitu 500x500px memiliki ukuran citra yang berbeda, dalam hal ini citra RGB lebih besar dibandingkan citra grayscale karena informasi yang tersimpan didalam citra RGB lebih banyak dibanding dengan citra grayscale, sehingga dalam pengujian ini citra grayscale lebih cepat diproses dibanding dengan citra RGB baik dalam hal enkripsi maupun dekripsi.

3. Pengaruh perbedaan kunci pada hasil enkripsi dan dekripsi. Pada pengujian ini dilakukan input data pada file citra yang sama dengan kunci yang berbeda baik dari panjang kunci dan jenis kunci.

Gambar 12 merupakan gambar yang dipakai dalam pengujian ini, gambar ini memiliki dimensi sebesar 275x149 pixels.

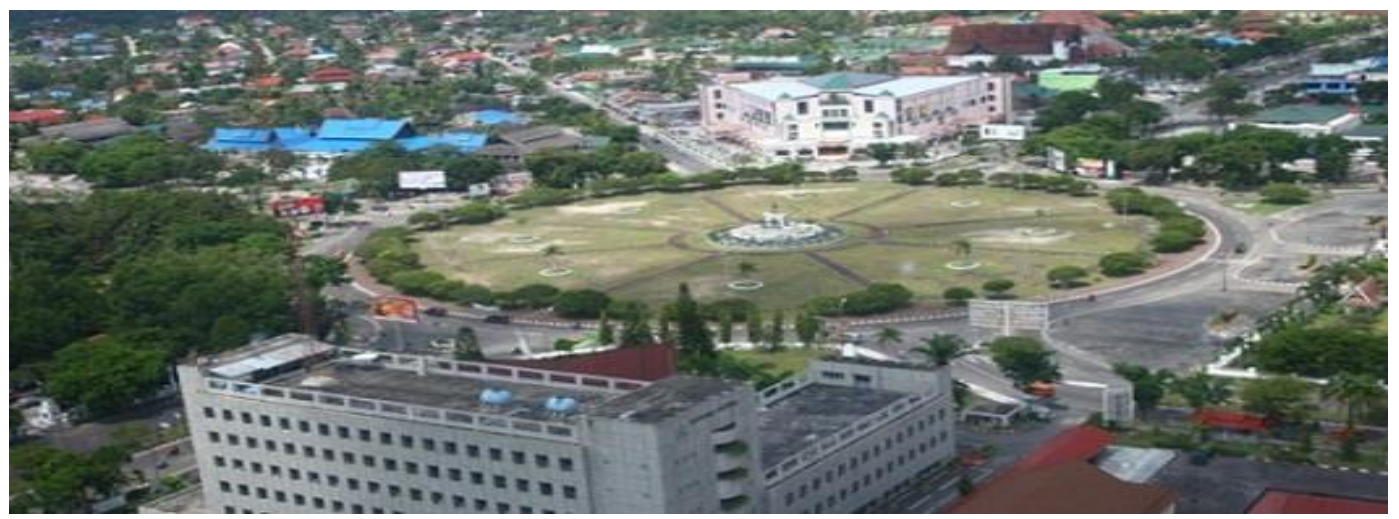

Gambar 8 Citra Gambar Input Pengujian Beda Kunci

Tabel 3 Pengaruh Perbedaan Kunci Pada Enkripsi

\begin{tabular}{|l|l|l|l|l|}
\hline \multicolumn{1}{|c|}{ Jenis Kunci } & \multicolumn{1}{|c|}{ Kunci } & $\begin{array}{c}\text { Ukuran } \\
\text { Sebelum } \\
\text { (Bytes) }\end{array}$ & $\begin{array}{c}\text { Ukuran } \\
\text { Sesudah } \\
\text { (Bytes) }\end{array}$ & $\begin{array}{c}\text { Durasi } \\
\text { (Detik) }\end{array}$ \\
\hline Huruf saja (16 Karakter) & abcdefghijklmnop & 50606 & 67504 & 0,007 \\
\hline Angka saja (16 Karakter) & 1234567891234567 & 50606 & 67504 & 0,007 \\
\hline Simbol saja (16 Karakter) & $<>,-=+\& *^{*} \% \#^{\wedge} \& ! \sim$ & 50606 & 67504 & 0,005 \\
\hline $\begin{array}{l}\text { Huruf, angka dan simbol }(16 \\
\text { Karakter) }\end{array}$ & teskunci1234=+-> & 50606 & 67504 & 0,007 \\
\hline Huruf saja $(\mathrm{x}<16$ Karakter) & tes & 50606 & 67504 & 0,007 \\
\hline Angka saja $(\mathrm{x}<16$ Karakter) & 1495 & 50606 & 67504 & 0,005 \\
\hline Simbol saja $(\mathrm{x}<16$ Karakter) & $+=>[\&$ & 50606 & 67504 & 0,006 \\
\hline $\begin{array}{l}\text { Huruf, angka dan simbol } \\
\text { (x<16 Karakter) }\end{array}$ & tes123\&= & 50606 & 67504 & 0,005 \\
\hline
\end{tabular}

Dapat dilihat pada tabel 3 pengujian perbedaan jenis kunci dan panjang kunci tidak berpengaruh pada ukuran hasil enkripsi, hal ini dikarenakan proses enkripsi yang dijalankan merupakan enkripsi 128 bit yang membutuhkan kunci 128 bit juga.

Code $:$ key = str_repeat $(\$$ key, floor $(16 / \operatorname{strlen}(\$ k e y))+1)$; 
Kode diatas merupakan kode untuk melakukan pengulangan kunci, kode ini dijalankan apabila kunci yang di-input panjangnya kurang dari 128 bit atau 16 byte. Terdapat operator division yang digunakan untuk mengetahui nilai div dari 16 dan panjang kunci. Hasil kemudian ditambahkan dengan satu serta dibulatkan dengan fungsi floor, sehingga kita mengetahui berapa kali kunci harus diulang agar kunci yang di-input memiliki panjang lebih dari atau sama dengan 16.

Code $: \$$ key $=\operatorname{substr}(\$ k e y, 0,16)$;

Kode diatas merupakan kode yang dijalankan setelah pengulangan kunci dilakukan untuk memastikan panjang kunci yang di-input adalah 128 bit. Pengaruh perbedaan jenis kunci dan panjang kunci pada enkripsi terhadap ukuran dan durasi proses enkripsi berlaku sama dengan proses dekripsi, hal ini dikarenakan pada fungsi dekripsi dijalankan fungsi str_repeat dan substr juga.

4. Durasi enkripsi dan dekripsi terhadap perbedaan resolusi citra input. Pada pengujian ini akan diambil 10 sampel dari gambar yang sama tetapi dengan resolusi yang berbeda. Semuanya akan dienkripsi dan dekripsi dengan kunci yang sama yaitu "teskunci".

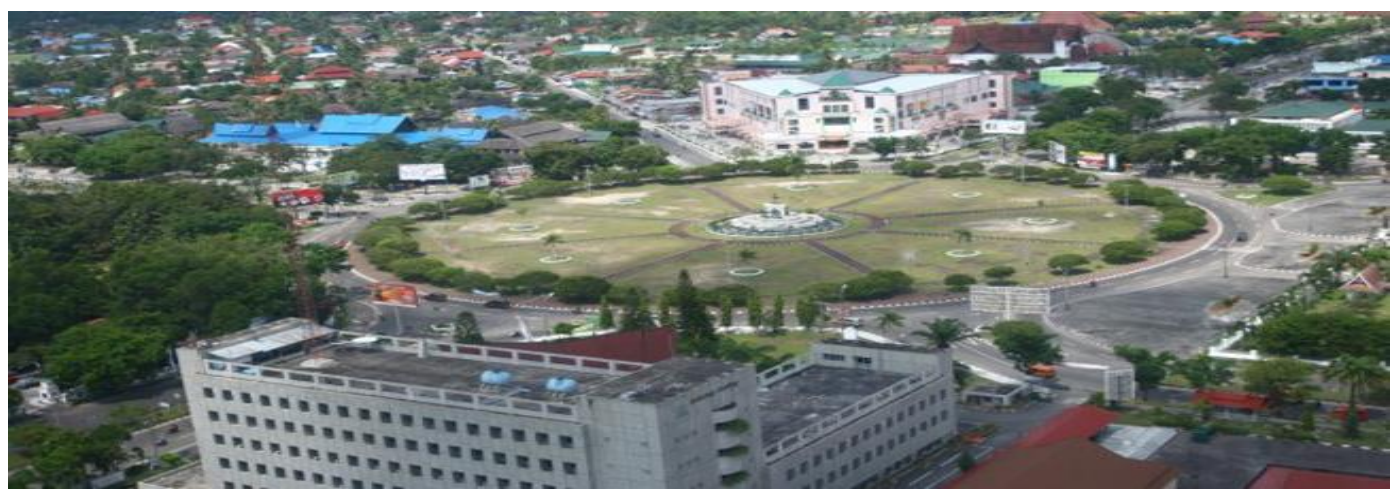

Gambar 9 Citra Uji Utama

Tabel 4 Uji Durasi Enkripsi Berdasarkan Ukuran

\begin{tabular}{|c|c|c|c|c|}
\hline Data & $\begin{array}{c}\text { Ukuran } \\
\text { (pixel) }\end{array}$ & $\begin{array}{c}\text { Ukuran } \\
\text { Sebelum } \\
\text { Enkripsi } \\
\text { (Bytes) }\end{array}$ & $\begin{array}{c}\text { Ukuran } \\
\text { Sesudah } \\
\text { Enkripsi } \\
\text { (Bytes) }\end{array}$ & $\begin{array}{c}\text { Durasi } \\
\text { (Detik) }\end{array}$ \\
\hline 1 & $650 \times 350$ & 149848 & 199824 & 0,013 \\
\hline 2 & $585 \times 315$ & 119230 & 158992 & 0,010 \\
\hline 3 & $527 \times 284$ & 104213 & 138976 & 0,006 \\
\hline 4 & $422 \times 228$ & 80877 & 107856 & 0,005 \\
\hline 5 & $338 \times 183$ & 62969 & 83984 & 0,004 \\
\hline 6 & $275 \times 149$ & 50606 & 67504 & 0,004 \\
\hline 7 & $224 \times 112$ & 41638 & 55536 & 0,003 \\
\hline 8 & $180 \times 98$ & 35545 & 47424 & 0,003 \\
\hline 9 & $144 \times 79$ & 30368 & 40512 & 0,003 \\
\hline 10 & $116 \times 64$ & 26083 & 34800 & 0,003 \\
\hline
\end{tabular}




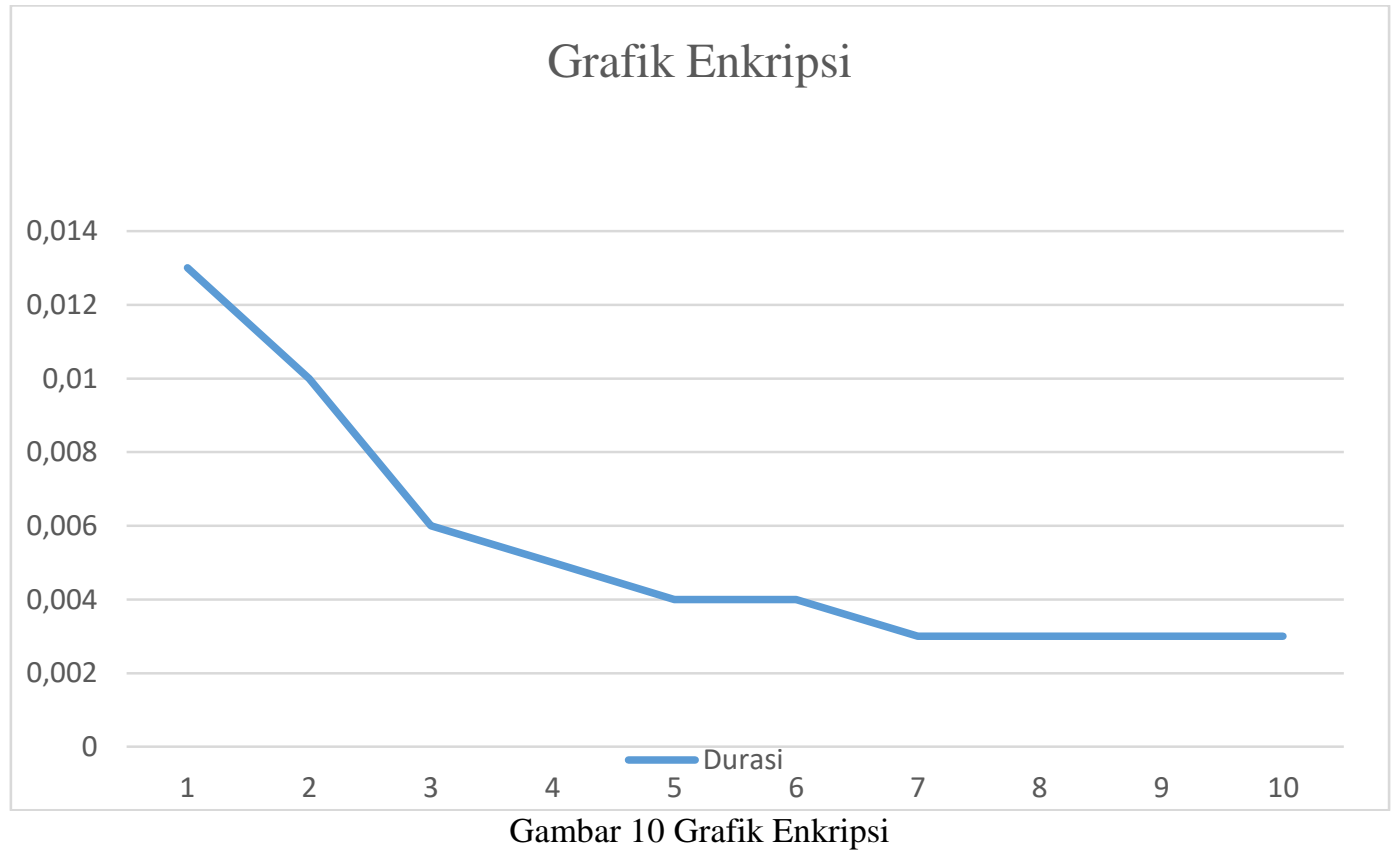

Tabel 5 Uji Durasi Dekripsi Berdasarkan Ukuran

\begin{tabular}{|c|c|c|c|c|}
\hline Data & $\begin{array}{c}\text { Ukuran } \\
\text { (pixel) }\end{array}$ & $\begin{array}{c}\text { Ukuran } \\
\text { Sebelum } \\
\text { Dekripsi } \\
\text { (Bytes) }\end{array}$ & $\begin{array}{c}\text { Ukuran } \\
\text { Sesudah } \\
\text { Dekripsi } \\
\text { (Bytes) }\end{array}$ & $\begin{array}{c}\text { Durasi } \\
\text { (Detik) }\end{array}$ \\
\hline 1 & $650 \times 350$ & 199824 & 149848 & 0,013 \\
\hline 2 & $585 \times 315$ & 158992 & 119230 & 0,009 \\
\hline 3 & $527 \times 284$ & 138976 & 104213 & 0,008 \\
\hline 4 & $422 \times 228$ & 107856 & 80877 & 0,006 \\
\hline 5 & $338 \times 183$ & 83984 & 62969 & 0,006 \\
\hline 6 & $275 \times 149$ & 67504 & 50606 & 0,004 \\
\hline 7 & $224 \times 112$ & 55536 & 41638 & 0,005 \\
\hline 8 & $180 \times 98$ & 47424 & 35545 & 0,006 \\
\hline 9 & $144 \times 79$ & 40512 & 30368 & 0,003 \\
\hline 10 & $116 \times 64$ & 34800 & 26083 & 0,006 \\
\hline
\end{tabular}




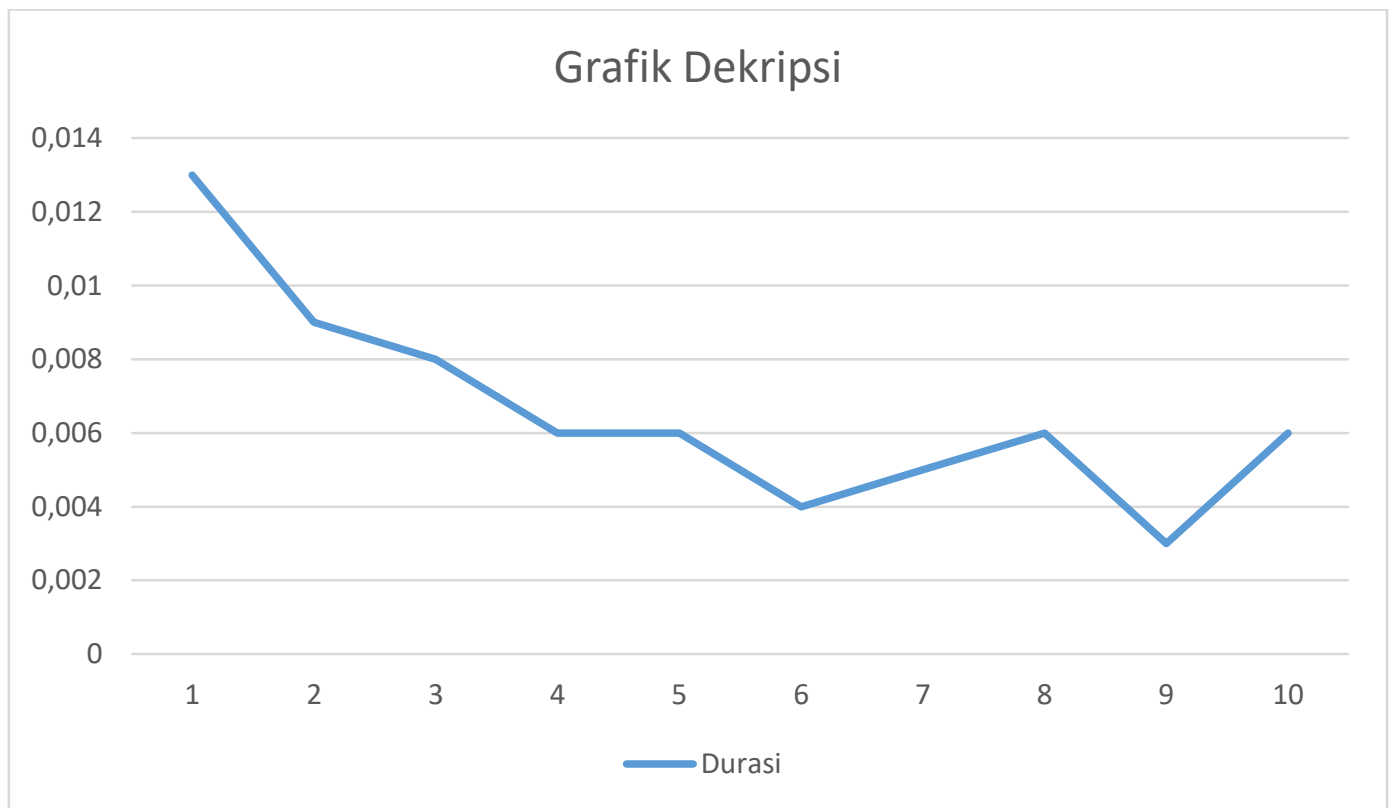

Gambar 11 Grafik Enkripsi

Dari tabel 4 dan 5 menunjukan bahwa terdapat perbedaan dalam running time dengan ukuran piksel yang berbeda. Makin besar ukuran piksel maka kumungkinan makin besar pula running time yang dibutuhkan. Dari semua uji coba enkripsi dan dekripsi yang dilakukan diperoleh nilai akurasi program sebagai berikut :

$$
\begin{gathered}
\text { nilai akurasi }=\frac{\text { File citra yang berhasil }}{\text { Seluruh file citra yang diuji }} \times 100 \% \\
\text { nilai akurasi }=\frac{14}{14} \times 100 \% \\
\text { nilai akurasi }=100 \%
\end{gathered}
$$

\section{Kesimpulan}

Berdasarkan hasil penelitian, maka dapat ditarik kesimpulan sebagai berikut. Program ini melakukan beberapa proses dalam menjalankan fungsinya yaitu SubBytes, ShiftRows, MixColumns, dan AddRoundKey. Tahapan-tahapan tersebut dijalankan sebanyak 10 round, karena kunci yang dipakai adalah 128 bit. Implementasi algoritma Rijndael dalam enkripsi dan dekripsi citra gambar digital, dapat ditarik kesimpulan sebagai berikut:

1. Hasil enkripsi merupakan sekumpulan kombinasi karakter yang tidak sama seperti aslinya, sehingga tidak dapat dimengerti oleh manusia biasa atau pihak - pihak yang tidak mengetahui kunci dan cara kerja algoritma yang dipakai dalam enkripsi tersebut.

2. Hasil enkripsi selalu sama dengan hasil dekripsi walaupun gambar yang di-input berbeda jenis, seperti citra RGB dan Grayscale. Keduanya akan kembali seperti keadaan awal sebelum dienkripsi.

3. Panjang kunci yang diinputkan tidak banyak mempengaruhi durasi enkripsi maupun dekripsi, karena basis kunci akan selalu menjadi 16 bytes meskipun kunci yang di-input-kan kurang dari 16 bytes.

4. Ukuran file yang dilakukan enkripsi dan dekripsi sangat berpengaruh dalam runnning time, semakin besar ukuran file yang diproses maka waktu yang dibutuhkan program untuk menyelesaikannya semakin lama juga. Hal ini berlaku sebaliknya, semakin kecil program maka waktu yang diperlukan akan semakin kecil. 
5. Nilai akurasi program adalah $100 \%$, hal ini didapat dari 14 data file citra gambar digital yang digunakan sebagai alat uji dan semuanya berhasil dienkripsi dan dikembalikan kebentuk awal dengan dekripsi.

\section{Daftar Pustaka}

[1] Aprianto dkk,. 2014, Rancang Bangun Aplikasi Enkripsi dan Dekripsi Gambar digital Menggunakan Algoritma Rijndael Berbasis Java SE. STMIK GI MDP.

[2] Bendi, 2012, Implementasi Algoritma Rijndael Untuk Enkripsi dan Dekripsi Pada Citra Digital. Universitas Katolik Musi Charitas.

[3] Bruce Schneier, 1996, Section 14.1 GOST, in Applied Cryptography, Second Edition. ISBN 0471-11709-9

[4] Deni Darmawan \& Deden Hendra Permana. 2013. Desain dan Pemrograman

[5] Website. Penerbit PT Remaja Rosdakarya : Bandung.

[6] Dony Ariyus, 2006, Kriptografi : Keamanan Data dan Komunikasi, Cetakan Pertama, Penerbit GRAHA ILMU, Yogyakarta.

[7] Dony Ariyus, 2008, Pengantar Ilmu Kriptografi: Teori Analisis \& Implementasi, Penerbit GRAHA ILMU, Yogyakarta.

[8] Irfan, 2016, Aplikasi Enkripsi Citra Menggunakan Algoritma Kriptografi Arnold Cat Map Dan Logistic Map. STMIK Bumigora : Mataram.

[9] Jogiyanto Hartono, 2005, Analisis dan Desain Sistem Informasi. Pendekatan Tersetruktur Teori dan Praktis Aplikasi Bisnis, Andi: Yogyakarta.

[10] Kustiyaningsih, Yeni. 2011, Pemrograman Basis Data Berbasis Web menggunakan PHP dan MySQL. Penerbit Graha Ilmu: Yogyakarta.

[11] Munir, 2012, Analisis Keamanan Algoritma Enkripsi Citra Digital Menggunakan Kombinasi Dua Chaos Map dan Penerapan Teknik Selektif. ITB: Bandung.

[12] Setyanigsih Emy, 2015, Kriptografi \& Implementasinya Menggunakan Matlab, Andi Publisher: Yogyakarta.

[13] Soumya, 2013. Design and Implementation of Rijndael Encryption Algorithm Based on FPGA. JITS: India.

[14] Supriyanto, 2008, Teknik Informasi \& Komunikasi SMP Kelas VII, Yudhistira : Yogyakarta.

[15] Suryadi dkk, 2014. Implementasi Algoritma Enkripsi Citra Digital Menggunakan Skema Transposisi Berbaris Pada Fungsi Chaos. FMIPA Universitas Indonesia.

[16] Rifki Sadikin, 2012, Kriptografi Untuk Keamanan Jaringan. Penerbit ANDI: Yogyakarta.

[17] Rinaldi Munir, 2006, Kriptografi, Penerbit INFORMATIKA, Bandung. 